\title{
THE INFLUENCE OF KOREAN POP CULTURE TOWARD CONSUMER INTENTION ON SELECTING KOREAN FOODS
}

Liswindwinanto Wicaksono

Swiss German University, Tangerang, Indonesia

Email: liswindwinantowicaksono@yahoo.com

\author{
Robert La Are
}

Swiss German University, Tangerang, Indonesia

Email: robert.are@sgu.ac.id

The purpose of the research is to find out the influence of Korean Pop Culture toward consumer intention on selecting Korean food. Korean Drama and Korean pop music are two phenomenal Korean pop culture which are spreaded around the world. In 1997, Korean Drama was first broadcast in China, following with the big step in 2004 where Korean Drama exported also to Hong Kong and Taiwan while Korean Pop Music start to gain popularity in the late of 1990s. In Indonesia, Korean Drama and K-pop music began to be popular in beginning of 2000's. Their popularity are followed by Korean foods in 2014. This research is to look specifically on whether Korean Pop Culture influence Indonesian people to choose Korean foods as their options. Using SPSS software and with simple linear regression method analysis, 100 respondents' data collected is processed through validity and reliability test, classical assumption test and hypothesis testing. The results show that Korean Pop Culture influence Indonesian people to choose Korean foods.

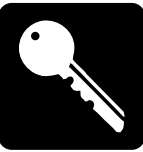

Consumer Intention, Fanaticism, K-pop music, Korean Drama,

Korean foods 


\section{INTRODUCTION}

$\mathbf{P}$ opular culture can be defined as a culture which is favoured or liked by many people (Storey, 2008). Examples of popular culture come from a wide array of genres, including popular music, print, cyber culture, sports, entertainment, leisure, fads, advertising and television. Sports and television are arguably two of the most widely consumed examples of popular culture, and they also represent two examples of popular culture with great staying power (Delaney, 2007).

South Korea has two famous popular culture around the world which are Korean drama and K-pop music. According to forms of Korean Culture and Information Service (2011), the fame of Korean Drama around the world started in 1997 when China's state run Korean drama "What is Love" and reached its success in attracting Chinese people. The success of Korean dramas in China was followed by "A Wish upon Star" which was broadcast in 1999. In 2003, NHK TV ran the Korean drama Winter Sonata and the result was an unprecedented cultural phenomenon. The big step happened in 2004 when "Jewel in the Palace" was exported to China, Hong Kong and Taiwan. After release in that countries, other countries such as Iran, the South East Asia region and even Europe tried to import this drama.

Meanwhile, Korean Pop Music started to gain popularity in the late 1990s. Following the success of H.O.T. in Hong Kong, Taiwan, and China, drama stars like Ahn Jae-wook and Park Yong-ha, boy bands NRG; Sechs Kies and Shinwha; and girl band Baby V.O.X. held concerts in packed venues in Taiwan and Hong Kong. BoA was the first Korean singers to turn genuinely global and earn cult status throughout Asia by gearing her career more to Japan and the United States than to Korea for recordings and live performances (Korean Culture and Information Service, 2011).

After two years the increasing of Korean music and drama popularity, Korean foods seems to be following the trend in Indonesia. People go to Korean Restaurants to try and even enjoy the foods. There are currently at least 150 Korean restaurants in Jakarta, catering to the palates of those hooked on Korean dramas and reality shows - or on the favourite food of their favourite actors and singers (Simanjuntak, 2015).

\section{LITERATURE REVIEW}

\section{II.I Framework Of Thinking}

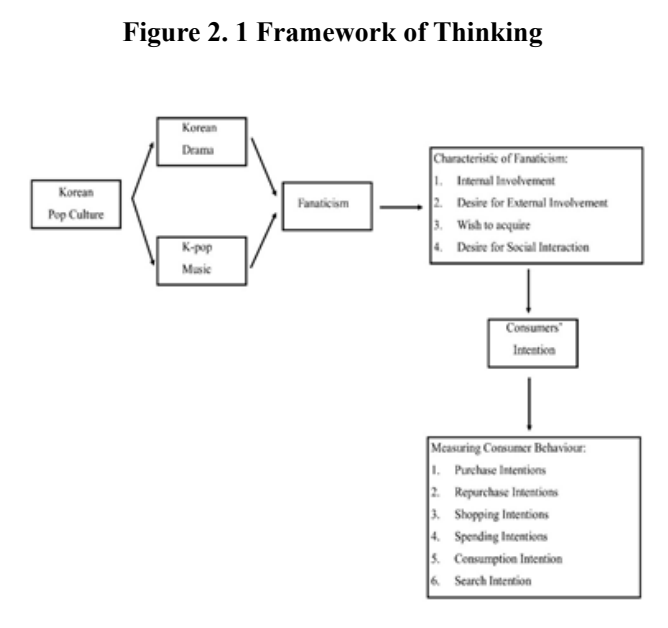

\section{II.II CULTURE}

Culture is a set of values, ideas, artefacts, and other meaningful symbols which help people to do communication, interpretation, and evaluation as members of society (Blackwell, 2006). According to Storey (2008), culture can be defined as a process of intellectual, spiritual, 
and aesthetic development. Besides that, culture can be defined also as a way of life whether as individual, society, or in a community.

\section{II.II.I Definition of Popular Culture}

Popular culture have several definitions. Raymond Williams suggests four current meanings about the meaning of "popular": 'well-liked by many people'; 'inferior kinds of work'; 'work deliberately setting out to win favour with the people'; 'culture actually made by the people for themselves' (Storey, 2008).

The first definition of popular culture is a culture that like by many people. The second definition of popular culture is cultures which are not selected because those cultures don't have standard to be classified as high culture. The third definition of popular culture is cultures which are made by people to be consumed for mass consumption (Storey, 2008).

According to Storey (2008), a fourth definition contends that popular culture is the culture that originates from 'the people'. It takes issue with any approach that suggests that it is something imposed on 'the people' from above. This is popular culture as folk culture: a culture of the people for the people. A fifth definition of popular culture, then, is one that draws on the political analysis of the Italian Marxist Antonio Gramsci, particularly on his development of the concept of hegemony. 'Hegemony' to refer to the way in which dominant groups in society, through a process of 'intellectual and moral leadership, seek to win the consent of subordinate groups in society. A sixth definition of popular culture is one informed by recent thinking around the debate on postmodernism. The main point to insist on here is the claim that postmodern culture is a culture that no longer recognizes the distinction between high and popular culture (Storey, 2008).

\section{II.III Fanaticism}

Fanaticism is defined as the degree of intensity to which one is a fan, with the level of involvement varying from low to high intensity. Fanaticism can be also be described also as the level of how much a person like or interest of a particular person, group, trend, artwork or idea (Thorne \& Bruner, 2006). According to Passmore (2003) in Chung et al. (2008), someone who is filled with an extreme personal passion and sometimes can be so excessice is called as Fanatics. According to some journals (e.g. Bristow and Sebastian 2001; Funk and James 2001; McAlexander, Schouten and Koenig 2002; Muñiz and O'Guinn 2001; Oliver 1999; Redden and Steiner 2000) in Thorne \& Bruner (2006), fanaticism is a unique form of loyalty characterised by extraordinary (strong, intense, and extreme) levels of commitment, allegiance, devotion, passion, emotional attachment, enthusiasm, and involvement.

\section{II.III.I Characteristics of fanaticism}

Anecdotal evidence from the work of Fine (1983), Kozinets (2001) and Belk and Costa (1998) in Thorne \& Bruner (2006), suggested the presence of a set of characteristics common to fans across different areas of fanaticism. Specifically, the available literature strongly indicates the existence of four characteristics driving fan behaviour and these are discussed below.

\section{Internal involvement}

A primary observation that has been made about fans is that they prioritize what they are interested with their energy, time, and resources intently. They get what make 
them happy and they don't mind if they friends and family don't like what they like. Fans are hard to change their opinion when they see what they like. Often, the fan will admit themselves as a fan (Thorne \& Bruner, 2006).

\section{Desire for external involvement}

Fans are motivated to show their involvement with something that they like with certain action. The fan's desire for external involvement manifests itself in many different ways depending upon the genre. Fans may decide to spend time reading about what they like, joining presentations or events, posting related to what they like on social media or joining conventions. External involvement activity may include wanting to buy a magazine to know the progress what the fan like. For intense expression, it can be spending a weekend dressed up and reenacting the activities of a mountain-man of a century and a half ago (Thorne \& Bruner, 2006).

\section{Wish to acquire}

According to Thorne \& Bruner (2006). Fans like to have some stuffs that related to what they want as a media to express themselves. There are some reason that can be the motivation for them. Fans may want to use the stuffs as a link when they do fans' activity. A shared community can be a media to express a total control of their life in this specific area. A fan like to have stuffs that only him who can have it. According to Hebdige (1979) in Thorne \& Bruner (2006), fans have desire to join activities to make the stuffs what they want to have. But it is not possible for fans to do that. So fans choose to have those stuffs as alternative. With having stuffs what they want, fans will feel that they are closed to what they like. If the stuff is valuable for them, some fans choose to sacrifice what their primary needs to get the item.

\section{Desire for social interaction}

Each fan may have different intensity about what they like. They feel that no one has the same fascination as they do. But, when each fan interact with other fans, the desire for interaction is strong. Fans usually are not satisfied when they interact with their friends, family, or someone they know who are not interested to what the fans like because they don't get the intensity like when they interact with other fans. To get convenience as a fan, fans usually interact with other fans with e-mail, chat room, and electronic mailing list. But there are some fans who prefer to meet by face to face such as fan club meetings, and organized conventions because it can satisfy them to interact with other fans (Thorne \& Bruner, 2006).

\section{II.IV Consumer Behaviour}

Consumer buyer behaviour refers to the buying behaviour of final consumers individual and households who buy goods and services for personal consumption (Kotler \& Armstrong, 2002). According to Kurtz \& Boone (2006), consumer behaviour is mental and physical activities of individuals who actually utilize the purchased goods and services.

\section{II.IV.I Characteristics Affecting}

\section{Consumer Behaviour}

Consumer's purchases are influenced strongly by cultural, social, personal, and psychological characteristics. For the most part, marketers cannot control such factors, but they must take them into account (Kotler \& Armstrong, 2002).

\section{Cultural Factors}

Cultural factor strongly influence consumer's purchases. Cultural factors 
exert a broad and deep influence on consumer behaviour Culture. Culture is the most basic cause of a person's wants and behaviour. Every group or society has a culture, and cultural influence on buying behaviour may vary greatly from country to country or even neighbourhood to neighbourhood (Kotler \& Armstrong, 2002).

\section{II.IV.II Consumer Intention}

One of alternative approach to predicting consumer behaviour involves asking consumers what they intent to do. In table 2.1, the data shows about the consumer intention to spend more or less money in a number different product categories. In essence, these consumers reported a form of spending intentions. Spending intention reflect how much money consumers think they will spend. But there are other types of consumer intention. Purchase intention is described as what consumers think they will buy. A special type of purchase intention is repurchase intentions, which indicate whether consumers anticipate buying the same products or brand again. Shopping intentions capture where consumers plan on making their products purchases. Search intentions indicate consumers' intention to engage in external search. Consumption intentions represents consumers' intentions to engage in a particular consumption activity (e.g., watch television, exercise, and browse the Internet (Blackwell, Miniard, Engel, Pai, \& Jooria, 2007).

Table 2. 1 Consumers' Spending Intentions: Winner and Losers (percent). Source: Blackwell (2012)

\section{II.V RESEARCH MODEL \& HYPOTHESIS}

Below is a constructed research model, built upon each variable indicator.

Figure 2. 2 Research Model

H1: Korean Pop Culture Fanaticism influences Indonesian people to try Korean foods select Korean foods as an option.

H0: Korean Pop Culture Fanaticism has no influence on Indonesian people to try and select Korean foods as an option.

\section{II.V RESEARCH METHODOLOGY}

The research used a causal explanatory research. Causal-explanatory research is used to find correlation between the variables that caused the phenomenon of a subject (Cooper \& Schindler, 2014). Primary and secondary data were both used to complete the research. Primary data sources are information obtained firsthand by the researcher on the variables of interest for the specific purpose of the study (Sekaran \& Bougie, 2014). Primary data of this research were collected with using questionnaire in forms of quantitative data. The secondary data were collected from every online journal, books and statistical data of Indonesia Census Bureau. As for this research, the independent variable were Korean Popular Culture and the dependent variable will be Consumer Behaviour. Independent variable was defined as a variable that influences the dependent variable and accounts for explaining its variance. 
Dependent variable was described as the variable of primary interest to the researcher (Sekaran \& Bougie 2014).

Table 3. 1 Operational Variable Table

\begin{tabular}{|c|c|c|c|c|}
\hline Variable I & ndicator & Conceptual Definition & Operational Definition & Scale \\
\hline \multirow{4}{*}{ Fanaticism } & $\begin{array}{l}\text { Internal } \\
\text { Involveme } \\
\mathrm{nt}\end{array}$ & $\begin{array}{l}\text { focusing their time, } \\
\text { energy and resources } \\
\text { intently on a specific } \\
\text { area of research }\end{array}$ & $\begin{array}{l}\text { How often people focus } \\
\text { their time and energy to } \\
\text { enjoy Korean Drama } \\
\text { and K-pop }\end{array}$ & Ordinal \\
\hline & $\begin{array}{c}\text { Desire for } \\
\text { External } \\
\text { Involveme } \\
\text { nt }\end{array}$ & $\begin{array}{l}\text { demonstrate their } \\
\text { involvement with the } \\
\text { area of their interest } \\
\text { through various } \\
\text { behaviours }\end{array}$ & $\begin{array}{l}\text { How often people get } \\
\text { involved with Korean } \\
\text { Drama and K-pop O }\end{array}$ & rdinal \\
\hline & $\begin{array}{l}\text { Wish to } \\
\text { Acquire }\end{array}$ & $\begin{array}{l}\text { a motivation to have or } \\
\text { get something }\end{array}$ & $\begin{array}{l}\text { people motivation to } \\
\text { have or get attributes of } \\
\text { Korean Drama or K- } \\
\text { pop }\end{array}$ & Ordinal \\
\hline & $\begin{array}{l}\text { Desire for } \\
\text { Social } \\
\text { Interaction }\end{array}$ & $\begin{array}{l}\text { desire to interact with } \\
\text { people }\end{array}$ & $\begin{array}{l}\text { How much time the } \\
\text { people spend with } \\
\text { others to talk about } \\
\text { Korean Drama and K- } \\
\text { pop }\end{array}$ & Ordinal \\
\hline \multirow{6}{*}{$\begin{array}{c}\text { Consumer } \\
\text { Intention }\end{array}$} & $\begin{array}{l}\text { Purchase } \\
\text { Intention }\end{array}$ & $\begin{array}{l}\text { What consumers think } \\
\text { they will buy }\end{array}$ & $\begin{array}{l}\text { What consumers think } \\
\text { about what foods will } \\
\text { be bought }\end{array}$ & Ordinal \\
\hline & $\begin{array}{l}\text { Re- } \\
\text { purchase } \\
\text { Intention }\end{array}$ & $\begin{array}{l}\text { whether consumers } \\
\text { anticipate buying the } \\
\text { same products or brand } \\
\text { again }\end{array}$ & $\begin{array}{l}\text { Whether consumers } \\
\text { wants to buy the same } \\
\text { Korean foods after taste } \\
\text { for the first time }\end{array}$ & Ordinal \\
\hline & $\begin{array}{l}\text { Shopping } \\
\text { Intention }\end{array}$ & $\begin{array}{l}\text { where consumers plan } \\
\text { on making their } \\
\text { product purchases }\end{array}$ & $\begin{array}{l}\text { where consumers plan } \\
\text { on eating Korean foods } Q\end{array}$ & rdinal \\
\hline & $\begin{array}{l}\text { Spending } \\
\text { Intention }\end{array}$ & $\begin{array}{l}\text { How much money } \\
\text { consumers think they } \\
\text { will spend }\end{array}$ & $\begin{array}{l}\text { How much money } \\
\text { consumers will spend } \\
\text { for Korean foods }\end{array}$ & Ordinal \\
\hline & \begin{tabular}{|c|c|}
$\begin{array}{c}\text { Consumpti } \\
\text { on } \\
\text { Intention }\end{array}$ \\
\end{tabular} & $\begin{array}{l}\text { consumers' intention to } \\
\text { engage in a particular } \\
\text { consumption activity }\end{array}$ & $\begin{array}{l}\text { consumers' intention to } \\
\text { consume Korean foods } \\
\text { regularly }\end{array}$ & Ordinal \\
\hline & $\begin{array}{l}\text { Search } \\
\text { Intention }\end{array}$ & $\begin{array}{l}\text { consumers' intention to } \\
\text { engage in external } \\
\text { search }\end{array}$ & $\begin{array}{l}\text { consumers' intention to } \\
\text { search information } \\
\text { about Korean foods }\end{array}$ & Ordinal \\
\hline
\end{tabular}

According to Sekaran \& Bougie (2014), population refers to the entire of group of people events, or things of interest that the researcher wishes to investigate. For this research, the author chose people who live in South Tangerang because of the limitation of the author to collect the respondents. According to Cooper \& Schindler (2014), Sample is a group of cases, participants, events, or records consisting of a portion of the target population. The author selected people who live in South Tangerang between 1834 years old because according to Korean Culture and Information Service (2011) the highest percentage based on age for enjoying Korean Drama and K-pop is $39 \%$ for age between 18-34 years old. Sample size was determined by proportion parameter sampling with $90 \%$ confidence level and $10 \%$ of maximum margin of error will be used (University Black Hill State).

$$
n=\frac{Z^{2} \alpha / 2}{4 e^{2}}
$$

$\mathrm{n}=$ Sample size

$\mathrm{Z}=\mathrm{Z}$ value

$\alpha=$ Standard deviation

$\mathrm{e}=$ Margin of error

Where the calculation are:

$$
\begin{gathered}
n=\frac{1.645^{2}}{4 \times(10 \%)^{2}} \\
n=\frac{2.71}{4 \times 0.01} \\
n=67.65 \sim 68
\end{gathered}
$$

This research used stratified random sampling method. Stratified random sampling is used by dividing population into meaningful segments; thereafter are drawing proportion to their original numbers in the population (Sekaran \& Bougie 2014).

Simple / linear regression method was used for data analysis. Regression analysis is a statistical technique that attempts to "explain" movements in one variable (Studenmund, 2006). Linear regression observation of $\mathrm{X}$ values to estimate or predict corresponding $\mathrm{Y}$ values (Cooper \& Schindler, 2014). Linear regression may be expressed as below equation.

$$
\begin{aligned}
\mathrm{Y}= & \beta 0+\beta 1 \mathrm{X} \\
\mathrm{Y} & : \text { dependent variable } \\
\mathrm{X} & : \text { independent variable } \\
\beta 0 & : \text { constant or intercept } \\
& \beta 1 \quad \text { : slope coefficient }
\end{aligned}
$$




\section{Normality test}

Normality is "the assumption that the observations, Yi are normally distributed with mean $\alpha+\beta \mathrm{Xi}$ and variance" (Bradley, 2007). Normality test is to indicate whether the residual values distributed normal or not. Kolmogorof Smirnov test can be conducted for each variable or its residual value. Data are normal if its residual values are above significance values set or it can be said if $P$ value $\geq \alpha$, h0 is accepted, data are normal. However if $\mathrm{p}$ value $<\alpha, \mathrm{h} 0$ rejected it means data are abnormal (Sunjoyo et al, 2013).

\section{Heteroscedasticity test}

"Heteroscedasticity is the violation of Classical Assumption V, which states that the observations of the error term are drawn from a distribution that has a constant variance" (Studenmund A. H., 2006). Heteroscedasticity is known as a situation where the conditional variance of the Y population varies with X. Glejser test can be used to detect heteroscedasticity. If $\mathrm{P}$ value $\geq \alpha, \mathrm{h} 0$ is accepted, data are free from heteroscedasticity, in the other hand if $\mathrm{p}$ value $<\alpha, \mathrm{h} 0$ rejected, it means data contains heteroscedasticity (Sunjoyo et al, 2013).

\section{T-test.}

T-test is a parametric test to determine the statistical significance between a sample distribution mean and a population parameter; used when the population standard deviation is un-known and the sample standard deviation is used as a proxy, whether $\beta 1=0$. Two-tailed test was used since the actual relationship is positive, negative or zero. The test follows the $t$ distribution for $n-2$ degrees of freedom:

$$
t=\frac{b 1}{s(b 1)}
$$

b1 was previously defined as the slope $\beta 1$ $\mathrm{s}(\mathrm{b} 1)$ is the standard error of $\beta 1$

Criteria of hypothesis acceptance or rejected:

P value $>\alpha(10 \%$ or 0.1$), h$ is accepted

p value $\leq \alpha(10 \%$ or 0.1$)$, h1 rejected

\section{IV.RESULT AND DISCUSSION}

\section{IV.I Classic Assumption Test}

Classical assumptions test is one of the requirement before a researcher can do hypothesis testing. Classical assumption test is done to minimize any error within the data collected that might affect the final results. In this research, author only do normality and heteroscedasticity test since the method is linear regression.

\section{A. Normality Test}

Normality test is one of the principal classic assumption test. Its purpose is to detect whether the residual value is distributed normal. The statistical hypotheses for normality test are:

H0: Data is normally distributed

H1: Data is not normally distributed

Later, the asymp.sig value will be compared to desired level of significance which in this case 0.05 . If it is higher than $0.05, \mathrm{H} 0$ is accepted. Author will use One-Sample Kolmogorov-Smirnov among several normality tests. The results of normality test can be seen below, on 
table 4.17.

Table 4. 1 Result of Kolmogorov Smirnov Test

\section{One-Sample Kolmogorov-Smirnov Test}

\begin{tabular}{|c|c|c|}
\hline & & $\begin{array}{c}\text { Unstandardize } \\
\text { d Residual }\end{array}$ \\
\hline $\begin{array}{l}\text { N } \\
\text { Normal } \\
\text { Parameters }{ }^{\mathrm{a}, \mathrm{b}} \\
\text { Most Extreme } \\
\text { Differences } \\
\text { Kolmogorov-S } \\
\text { Asymp. Sig. (2 }\end{array}$ & $\begin{array}{l}\text { Mean } \\
\text { Std. } \\
\text { Deviation } \\
\text { Absolute } \\
\text { Positive } \\
\text { Negative } \\
\text { lov Z } \\
\text { ed) }\end{array}$ & $\begin{array}{r}100 \\
.0000000 \\
3.35009833\end{array}$ \\
\hline
\end{tabular}

a. Test distribution is Normal.

b. Calculated from data.

This research's data asymp sig value is 0.526 , indicating that the data is distributed normal.

\section{B. Heteroscedasticity Test}

In every research, researcher aim for a homogeneous answer from its respondents. Heteroscedasticity is a test to determine whether the answer from respondent is homogenous or not. It does not mean that the answer cannot be varied, however their variation should be still in the range of standard deviation. The statistical hypotheses of heteroscedasticity test are:

H0: Data do not contain heteroscedasticity

H1: Data contain heteroscedasticity

Researcher will aim for $\mathrm{H} 0$ being accepted. In order to accept $\mathrm{H} 0$, the value of sig should be higher than 0.05 (level of significance). The result of heteroscedasticity test can be seen from table 4.18 .
Table 4. 2 Result of Glejser Test Coefficientsa

\begin{tabular}{|c|c|c|c|c|c|}
\hline \multirow[b]{2}{*}{ Model } & \multicolumn{2}{|c|}{$\begin{array}{l}\text { Unstandardize } \\
\text { d Coefficients }\end{array}$} & \multirow{2}{*}{$\begin{array}{c}\text { Standar } \\
\text { dized } \\
\text { Coeffic } \\
\text { ients } \\
\text { Beta }\end{array}$} & \multirow[b]{2}{*}{$\mathrm{t}$} & \multirow[b]{2}{*}{ Sig. } \\
\hline & B & $\begin{array}{l}\text { Std. } \\
\text { Error }\end{array}$ & & & \\
\hline $\begin{array}{ll}1 \text { Con } \\
\text { stant })\end{array}$ & 3.961 & .892 & & $\begin{array}{r}4.44 \\
1\end{array}$ & .000 \\
\hline $\begin{array}{l}\text { TotX } \\
1\end{array}$ & -.091 & .100 & -.157 & .901 & .370 \\
\hline $\begin{array}{l}\text { TotX } \\
2\end{array}$ & .188 & .124 & .292 & $\begin{array}{r}1.51 \\
6\end{array}$ & .133 \\
\hline TotX & & & & - & \\
\hline 3 & -.210 & .134 & -.234 & $\begin{array}{r}1.56 \\
7\end{array}$ & .120 \\
\hline $\begin{array}{l}\text { TotX } \\
4\end{array}$ & -.053 & .091 & -.064 & .579 & .564 \\
\hline
\end{tabular}

a. Dependent Variable: ABS

Sig value of each variable exceed 0.05 , therefore the data is freed from Heteroscedasticity.

\section{IV.II Hypothesis Testing}

There are some ways to test the hypotheses, test used is determined by a research model. This research is a simple linear regression with partial relation within each variable, thus t-test is the most suitable to be used. In this research there will be only one hypothesis, it is about to prove relationship of $\mathrm{X}$ to $\mathrm{Y}$. The hypothesis test is:

\section{H1: Korean Pop Culture Fanaticism influence Indonesian people to try and select Korean foods as an option.}

With statistical hypotheses of:

H0: Korean Pop Culture Fanaticism has no influence on Indonesian people to try and select Korean foods as an option.

H1: Korean Pop Culture Fanaticism 
influences Indonesian people to try and select Korean foods as an option.

The Korean Pop Culture fanaticism have sig value of 0.000 . In order for $\mathrm{H} 1$ to be accepted, the sig value should be less than alpha (0.10). The results for t-test can be seen on table below:

Table 4. 3 T-test

Coefficients $^{\mathbf{a}}$

\begin{tabular}{|c|c|c|c|c|c|}
\hline \multirow[b]{2}{*}{ Model } & \multicolumn{2}{|c|}{$\begin{array}{c}\text { Unstandardiz } \\
\text { ed } \\
\text { Coefficients }\end{array}$} & \multirow{2}{*}{$\begin{array}{c}\begin{array}{c}\text { Standa } \\
\text { rdized } \\
\text { Coeffi } \\
\text { cients }\end{array} \\
\text { Beta }\end{array}$} & \multirow[b]{2}{*}{$\mathrm{t}$} & \multirow[b]{2}{*}{ Sig. } \\
\hline & B & $\begin{array}{c}\text { Std. } \\
\text { Error }\end{array}$ & & & \\
\hline $\begin{array}{l}1 \text { Con } \\
\text { stant } \\
\end{array}$ & $\begin{array}{r}10.58 \\
3\end{array}$ & 1.475 & & $\begin{array}{r}7.1 \\
75\end{array}$ & $\begin{array}{r}.00 \\
0\end{array}$ \\
\hline $\begin{array}{l}\text { Tota } \\
\text { IX }\end{array}$ & .265 & .042 & .541 & $\begin{array}{r}6.3 \\
66\end{array}$ & $\begin{array}{r}.00 \\
0\end{array}$ \\
\hline
\end{tabular}

a. Dependent Variable: totally Source: SPSS

Based on the highlighted sig value above, it can be conclude that Korean Drama and $\mathrm{K}$-pop music influence Indonesian people to try and select Korean foods as option or in other words, the $\mathrm{H} 1$ is accepted.

\section{IV.III Discussion}

Fanatic's enthusiasm is so extreme it is sometimes considered excessive. Examples of fanaticism to a brand, product, or activity can be found in seminal studies of extremely loyal, brand-worshipping consumers, such as core participants of brand communities, brand cults, and various subcultures of consumption (Chung et al. 2008). With over 800 million views on YouTube Gangnam Style has become a cultural sensation, but K-Pop has been around longer than Psy and its influence has lent a hand in elevating South Korea in the consciousness of Asia and the world, with effects that go well beyond the entertainment industry. Culture is helping to bolster the country's "soft power" and build its influence (Choi \& Nip, 2012). Soft power is a concept developed by Joseph Nye of Harvard University to describe the ability to attract and co-opt rather than by coercion (hard power), using force or giving money as a means of persuasion (Nye, 2012). In Cambodia's capital Phnom Penh, a television station that only broadcasts the latest in Korean music is one of the most popular entertainment channels. Korean celebrities such as Rain sell cosmetic products while companies such as Samsung have been on the ground for years selling their wares to the Cambodians, including phones marketed using K-pop stars. "We had 10 million visitors from overseas last year. They bring an economic contribution to society," says Peter Kim. Tourism to the country has been growing by double digits over the past five years, around 75 per cent of it driven by Asian visitors, says Kim (Choi \& Nip, 2012). Below is the table shown how big the influence of Korean Drama and K-pop towards selecting Korean foods.

Table 4. 4 Coefficient Correlation Table Model Summary

\begin{tabular}{|c|c|c|c|c|}
\hline $\begin{array}{l}\text { Mo } \\
\text { del }\end{array}$ & $\mathrm{R}$ & $\begin{array}{c}\mathrm{R} \\
\text { Squar } \\
\mathrm{e} \\
\end{array}$ & $\begin{array}{l}\text { Adjusted } \\
\text { R Square }\end{array}$ & $\begin{array}{c}\text { Std. } \\
\text { Error of } \\
\text { the } \\
\text { Estimate }\end{array}$ \\
\hline 1 & $.541^{\mathrm{a}}$ & .293 & .285 & 3.52886 \\
\hline
\end{tabular}




\section{CONLUSIONS RECOMMENDATION}

\section{V.I Conclusions}

The objective of this research is to find out whether Korean Pop Culture influence Indonesian people to try Korean foods. Based on the results, H1 is accepted, Korean drama and pop music influence Indonesian people who live in South Tangerang Area to try Korean foods with amount of $29.3 \%$.

\section{V.II Recommendation For Future Research}

It is suggested to do deeper research to give more details of the impact for each variable. This research only covers people who live in South Tangerang area who are in 18 up to 34 years old, it will be challenging to widen the area of research, for example in Jakarta, Bogor, Depok, Tangerang, and Bekasi (Jabodetabek) region and the range of age of the respondents, for example people who are more than 34 years old. Other factor can also be added to the future research to compare the impact.

\section{REFERENCES}

Blackwell, Miniard, Engel, Pai, N., \& Jooria, W. (2007). Consumer Behaviour. Cengage Asia Learning Pte.Ltd.

Blackwell, R., D’Souza, C., Taghian, M., Miniard, P., \& Engel, J. (2006). Consumer Behaviour An Asia Pacific Approach. Cengage Learning Australia Ply Limited.

Bradley, T. (2007). Essential statistics for economics, business and management. New Jersey: John Wiley.

Choi, C., \& Nip, A. (2012). How Korean culture stormed the world.

Chung, Emily, Beverland, Michael, and Quester, Pascale (2007). Becoming a Fanatic: An

Exploration into the Development of Extraordinary Devotion to a Consumptive Object. ANZMAC 2007 Conference: Consumer Behaviour.

Chung, Emily, Beverland, Michael M., Farrelly, Francis, and Quester, Pascale (2008). Exploring

Consumer Fanaticism: Extraordinary Devotion in the Consumption Context. Advances in Consumer Research - North American Conference Proceedings, Vol. 35, pp. 333-340.

Cooper, \& Schindler. (2014). Business research methods. New York: McGrawHill.

Delaney, T. (2007). Pop Culture: An Overview.

Korean Culture and Information Service (2011). The Korean Wave: A New Pop Culture Phenomenon. Korean Culture and Information ServiceMinistry of Culture, Sports and Tourism.

Kotler, P., \& Armstrong, G. (2002). Principles of Marketing. New Jersey: Pearson Education, Inc.

Kurtz, \& Boone. (2006). Principle of Marketing. Thomson.

Nye, J.S. (2012). China's Soft Power Defisit to catch up. The Wall Street Journal.

Sekaran, U., \& Bougie, R. (2013). Research methods for business : a skill building approach. West Sussex: John Wiley.

Scott Thorne Gordon C. Bruner, (2006),"An exploratory investigation 
of the characteristics of consumer fanaticism", Qualitative Market Research: An International Journal, Vol. 9 Iss 1 pp. $51-72$

Simanjuntak, T. ZB. (2015). Korean food gives Jakarta food for thought.

Storey, J. (2008). Cultural Theory and Popular Culture: An Introduction.Pearson
Studenmund, A. (2006). Using econometrics : a practical guide. Boston: Pearson.

Sunjoyo, R. S. (2013). Aplikasi SPSS SMART Riset. Bandung: Alfabeta.

University Black Hill State - "Sample Size and Margin of Error." 